\title{
Response to supplementary feeding by lactating Zebu cows in northern Cameroon
}

\author{
A Njoya ${ }^{1,}$ X Lacmene ${ }^{2}$, R Njwe ${ }^{2}$ \\ 'Animal and Veterinary Research Institute (IRZV) and Garoua Project Phase II, PO Box 1073, Garoua; \\ zUniversity of Dschang, PO Box 222, Dschang, Cameroon
}

Milk production in Cameroon is based on local breeds with low productivity attributed not only to genetics, but also to inadequate quantity of low quality feed. Our objective was to quantify and evaluate the short-term response of lactating Zebu cows to supplementary feeding during the dry season in northern Cameroon.

The study which lasted for 9 weeks including 2 weeks of adaptation was carried out on a village farm. 14 lactating Zebu cows (mean : 5 years old) grazing a dry season pasture were used, 12 cows in first lactation, and 2 in second lactation. The experiment began on 2 nd to $3 r d$ month of lactation. The mean initial live weight (LW) was $284 \pm 45 \mathrm{~kg}$ ( \pm SD) and body condition score (BCS) was $2.46 \pm 0.39$ on a scale of 1 to 4 . The average milk production was $1.25 \pm 0.7 \mathrm{l} / \mathrm{cow}$. Cows were paired according to body weight and milk production, then assigned to either the supplemented treatment or the control. Cows were individually fed $1.5 \mathrm{~kg} /$ cow/day of a supplement composed of 67 p. 100 cottonseed meal, 26.5 p.100 corn and 6.5 p.100 fish meal just after morning milking. The supplement contained 34.4 p. 100 crude protein and $2.82 \mathrm{Mcal}$ of metabolizable energy $/ \mathrm{kg}$ dry matter.

Body weight of cows and caives was recorded weekly. BCS of cows was also taken weekly. After 4 weeks into the trial, blood samples were collected from the jugular vein of 5 cows per treatment into tubes containing EDTA for the determination of packed cell volume (PCV), plasma non-esterified fatty acid (NEFA), urea, albumin (Alb), total proteins (TP), inorganic phosphorus $(\mathrm{Pi}$ ) and haemoglobin $(\mathrm{Hb})$. Blood was also sampled in sodium fluoride tubes for glucose assay. The metabolic profile was assayed on an Autoanalyser CoulterTM. PCV was determined using a hematocrit centrifuge and reader, and $\mathrm{Hb}$ with a Coulter Counter $57 \mathrm{TM}$.

Supplementation significantly increased milk yield and weight gain (ADG) of lactating cows $(P<0.01)$. BCS tended to increased with supplementation $(\mathrm{P}<0.1)$. $\mathrm{PCV}, \mathrm{Hb}, \mathrm{Alb}$ and TP were not affected, but urea $(P<0.05)$ and $P i$ $(P<0.1)$ were increased by supplementation. The control had a higher glucose level compared with the supplemented cows $(P<0.05)$. Calves of supplemented dams had a higher ADG than those from control dams $(P<0.05)$. The lower plasma urea of the control group supported evidence that protein was a limiting nutrient for the cows grazing low quality pasture (Hennessy DW, 1983, S Afr J Anim Sc, 13, 9-11). The higher levels of plasma glucose and NEFA coupled with the lost of body weight by the control cows were indicators of the nutritional stresses leading to energy mobilisation from the body reserves to support milk synthesis and agreed with Lee et al (1985, Aust J Agric Res, 36, 729741). Although economically justified, milk production failed below the expected yield with the type of supplement fed and the pasture available.

In conclusion, strategic supplementary feeding during the dry season can reduce nutritional stresses and improve the productivity of lactating Zebu cows and economic benefits to small farmers. However, where adequate feed supplies are available, crossbreeding Zebu with European dairy breeds will be recommended for an effective long-term plan aimed at covering demand for milk of the fast growing urban population in the sahelian regions.

\begin{tabular}{|c|c|c|c|c|c|c|c|c|c|c|c|c|}
\hline & $\begin{array}{l}\text { Avg. } \\
\text { milk } \\
\text { (I/d) }\end{array}$ & $\begin{array}{l}\text { ADG } \\
\text { cow } \\
(\mathrm{g} / \mathrm{d})\end{array}$ & $\begin{array}{l}\text { BCS } \\
\text { cow }\end{array}$ & $\begin{array}{c}A \overline{A D G} \\
\text { calf } \\
\text { (g/d) }\end{array}$ & $\begin{array}{l}\text { PCV } \\
\text { p.100 }\end{array}$ & $\begin{array}{l}\mathrm{Hb} \\
(\mathrm{g} / \mathrm{l})\end{array}$ & $\begin{array}{l}\text { NEFA } \\
(\mathrm{mg} / \mathrm{l})\end{array}$ & $\begin{array}{l}\text { Gluc } \\
(g / l)\end{array}$ & $\begin{array}{l}\text { Urea } \\
(g / l)\end{array}$ & $\begin{array}{c}\text { TP } \\
(g / l)\end{array}$ & $\begin{array}{c}\text { Alb } \\
(\mathrm{g} / \mathrm{l})\end{array}$ & $\underset{(\mathrm{mg} / /)}{\mathrm{Pi}}$ \\
\hline & 1 & & 3. & & 26 & & & $4^{a}$ & & 75.0 & .4 & 32 \\
\hline & $1.0 \mathrm{~b}$ & $08^{b}$ & 2.6 & $158^{b}$ & 26.1 & 9 & 0.271 & $0.60 \mathrm{~b}$ & 0.16 & 74.8 & 38.4 & 28 \\
\hline
\end{tabular}

